\title{
Ideology in Chimamanda Ngozi Adichie's Purple Hibiscus (2003)
}

\author{
Daria Tunca \\ University of Liège, Belgium
}

\begin{abstract}
This article focuses on the first novel by Nigerian writer Chimamanda Ngozi Adichie, Purple Hibiscus (2003). It examines how religious prejudice is encoded in the account of the book's autodiegetic narrator, a fifteen-year-old girl whose father is a violent, extremist Igbo Catholic. Based on a close reading of the text, the essay argues that an analysis of the novel's use of speech and thought presentation may contribute to the assessment of the main character's evolving ideological stance. It is suggested that the resulting appraisal of the narrator's development provides key insights into the interpretation of the book.
\end{abstract}

The world is like a Mask dancing. If you want to see it well you do not stand in one place. Chinua Achebe, Arrow of God (1974: 46)

\section{Introduction}

Young Nigerian author Chimamanda Ngozi Adichie has, in recent years, attracted the attention of critics and the general public more than any other African writer of her generation. Numerous reviews of her fiction can be found in both newspapers and academic journals and, in spite of her relatively recent appearance on the international literary scene, several scholarly essays examining her two novels, Purple Hibiscus (2003) and the Orange prize-winning Half of a Yellow Sun (2006), have already been published. Thus, much has been written about the themes and motifs found in Adichie's work, particularly Purple Hibiscus; however, the stylistic qualities of the author's literary output have seldom constituted the focus of attention. Indeed, while many commentators have offered cursory comments on her felicitous use of language, the literary function of her prose's formal characteristics has received little consideration. In the following essay, I would like to concentrate on Adichie's first novel, Purple Hibiscus, and suggest that the analysis of some of 
Published in: English Text construction 2.1 (2009), pp. 121-131.

Status: Postprint (Author's version). Please contact John Benjamins Publishing House for further reprinting or re-use.

the book's linguistic strategies may contribute to a deeper understanding of the story. More specifically, I wish to examine how ideology ${ }^{1}$ is woven into the account of the first-person narrator, for I believe that the writer's subtle use of style shapes the reader's perception of the main character, a view that ultimately affects his or her appraisal of the message conveyed by the novel. Before carrying out my analysis, I shall provide a few facts relating to the content of Purple Hibiscus, and outline the motivations behind my methodological choices.

Purple Hibiscus centres on an Igbo family living in the south-eastern part of Nigeria in the late twentieth century. Through the eyes of a fifteen-year-old female narrator, Kambili Achike, the reader discovers that her father, Eugene, is a staunch Catholic with a multifaceted personality that can only be captured in a series of paradoxes: an affluent businessman, he makes large donations to the local church but displays very little of this generosity towards his father, a follower of traditional Igbo religion whom he repeatedly refers to as a "heathen"; he speaks up against the Nigerian military dictatorship in the newspaper he publishes, but he frequently beats his wife Beatrice and his children, Kambili and her brother Jaja, thereby brutally imposing his extremist religious views on them. The two adolescents provisionally escape the suffocating atmosphere of their home in Enugu when they are invited by their Aunt Ifeoma to spend a few days in Nsukka. Eugene's sister, a widowed university lecturer, lives in a small apartment with her three children, Amaka, Obiora and Chima. Despite the financial challenges faced by the family, Ifeoma's flat resounds with chatter and laughter. This relaxed environment provides Kambili and Jaja with an alternative model to the climate of fear that pervades the paternal home. Above all, the Achike children's brief stay in Nsukka temporarily gives them a new-found sense of serenity, symbolized by their aunt's experimental, hybrid purple hibiscus, "rare, fragrant with the undertones of freedom" (16). ${ }^{2}$

Because Kambili matures as the novel progresses, some scholars have described Adichie's book as a Bildungsroman (e.g. Bryce 2008: 58; Hron 2008: 30). While not all critics have explicitly categorized the narrative as such, few have denied that the main character develops from an introverted, acquiescent girl into a more self-assured young woman. For instance, she initially keeps her father's physical abuse shrouded in silence, but later admits to the extent of his maltreatment during a conversation with her cousin Amaka. The changes in Kambili's attitude have been noted by many critics, and they are indeed highly relevant to the analysis of the character's evolution. Nevertheless, a simple description of the protagonist's actions in the story - such as the act of speaking in which she eventually engages - does little to convey the complexity of her intellectual development, a factor which I consider central to the interpretation of the book. In other words, an in-depth analysis of Kambili's personality 
Published in: English Text construction 2.1 (2009), pp. 121-131.

Status: Postprint (Author's version). Please contact John Benjamins Publishing House for further reprinting or re-use.

should not merely take notice of how the character behaves, but also examine how she thinks, i.e. how she, as a narrator, perceives her environment and encodes her impressions into her narrative discourse.

\section{Towards an analysis of the narrator's ideology}

In Purple Hibiscus, Kambili's admiration for Eugene initially knows no limits, despite the brutal treatment the latter inflicts on his family. The teenager constantly yearns for her father's approval, and attaches profound importance to being a source of pride to him (see e.g. Adichie 2003: 53, 94, 137, 260). Directly linked to this compulsion to please Eugene is the fact that, for a long time, Kambili dismisses the thought that any standards which are not her father's may be equally, or even more, valid than his. In this respect, I concur with Karen Bruce that "Kambili has internalised her father's authority to such an extent that it has become an unquestioned part of the way she experiences and interacts with the world" (n.d.). Since the narrator at first applies Eugene's principles on all planes (whether religious, cultural or moral), "authority" in Bruce's sentence might equally read "values", giving the analysis an ideological slant. I would like to suggest that, stylistically speaking, the author represents Kambili's intense devotion to her father - an admiration that leads to her unwitting "internalization" of his moral standards - by using mechanisms of speech and thought presentation skilfully. ${ }^{3}$ More precisely, I wish to demonstrate how Adichie exploits the two points of view inherent in both indirect and free indirect speech (Leech and Short 2007: 256-257, 270) to delineate her narrator s ideological stance.

Indirect and/or free indirect speech $^{4}$ is often employed to subtle effect in Purple Hibiscus, particularly when Kambili reports the convictions and judgements that Eugene imparts to his family:

[Papa] looked sad; his rectangular lips seemed to sag. Coups begat coups, he said, telling us about the bloody coups of the sixties, which ended up in civil war just after he left Nigeria to study in England. A coup always began a vicious cycle. Military men would always overthrow one another, because they could, because they were all power drunk. Of course, Papa told us, the politicians were corrupt, and the Standard [Eugene's newspaper] had written many stories about the cabinet ministers who stashed money in foreign bank accounts, money meant for paying teachers' salaries and building roads. (24)

As the autodiegetic narrator of the book, Kambili is also the fixed internal focalizer, which 
Published in: English Text construction 2.1 (2009), pp. 121-131.

Status: Postprint (Author's version). Please contact John Benjamins Publishing House for further reprinting or re-use.

means that it is only from her point of view that situations and events are rendered. All three major types of speech presentation (direct speech, indirect speech and free indirect speech) occur in the novel, while thought presentation can be found in the forms of indirect thought, free indirect thought (including represented perceptions) ${ }^{5}$ and free direct thought in the last section of the novel. The opening sentence of the above quotation may be considered an instance of represented perception: Kambili guesses that her father is sad, based on his appearance, while he may in fact be experiencing other emotions. Because this sentence is a physical description in free indirect thought, ${ }^{6}$ the first clause of the following sentence, "Coups begat coups", might also be perceived as such until this mistaken impression is corrected by the reporting clause "he said", indicating that the sentence is an instance of indirect speech in which the reporting and reported clauses have been inverted. This retrospective rectification may be considered a case of "garden path effect", a psycholinguistic phenomenon whereby the syntax of a sentence is suggestive of an interpretation that turns out to be the wrong one. ${ }^{7}$ Importantly, although the impression of having encountered free indirect thought is corrected, "the original effect is not entirely subsumed" (Leech and Short 2007: 267).

This syntactical construction in indirect speech is followed by two sentences that cannot unambiguously be attributed to either Kambili or her father: "A coup always began a vicious cycle. Military men would always overthrow one another, because they could, because they were all power drunk" (24). On formal linguistic criteria alone, it is impossible to decide whether these sentences are instances of free indirect thought, in which case they mirror Kambili's considerations, inspired by her father's opinions, or if they exemplify a "slip" into the free indirect speech mode (Leech and Short 2007: 272) and are a rendering of Eugene's discourse. Arguably, the topic, the elaborateness of the subject matter and the vocabulary give Eugene an edge over his daughter but, formally speaking, free indirect thought is blended into free indirect speech, resulting in polyphony. ${ }^{8}$

The beginning of the next paragraph, the adverb "of course", followed by the reporting clause "Papa told us", is another example of an inversion of the reporting and reported clause. As in the first case, one has the fleeting impression that the adverb reflects Kambili's convictions, while the two words are in fact part of an indirect speech construction and therefore most likely uttered by Eugene. Once the "authorship" of the reported clause has been established, one is inclined to reinterpret the last two sentences of the preceding paragraph as free indirect speech.

The manipulation of speech presentation, illustrated in garden path effects and the 
Published in: English Text construction 2.1 (2009), pp. 121-131.

Status: Postprint (Author's version). Please contact John Benjamins Publishing House for further reprinting or re-use.

blending of the spheres of free indirect thought and free indirect speech, blurs the boundaries between Kambili's and her father's words. Provided that the ambiguous passages discussed above are all in (free) indirect speech, undoubtedly the most likely interpretation, this stylistic technique makes the narrator appear as though she has interiorized Eugene's views to such an extent that they come across as being hers. She "forg[ets] [her]self" (25), has no critical distance vis-à-vis her father's teachings and weaves his speech into hers. In other words, she has literally internalized his values and authority, for his ideas cannot be distinguished from hers on the formal level of the text. ${ }^{9}$

The impression that Eugene's shadow looms over the narrative is not restricted to passages in which Kambili reports her father's speech. His influence works more insidiously, as shown by her use of the word "mushroom" in her description of a Catholic mass:

The congregation said "Yes" or "God bless him" or "Amen," but not too loudly so they would not sound like the mushroom Pentecostal churches. (5)

It matters little whether the modifying noun "mushroom" reflects Kambili's opinion alone or whether it is a view she shares with the entire congregation. Since the passage bears no trace of ironic distance, it is clear in both cases that Kambili espouses the belief that Pentecostal churches are spreading like parasites. In a subsequent passage that nevertheless occurs chronologically before the first, Eugene is attributed the following words in direct speech:

That young priest, singing in the sermon like a Godless leader of one of these Pentecostal churches that spring up everywhere like mushrooms. (29)

Eugene's remark on the buildings erected by the Pentecostal movement sheds light on Kambili's source for the pejorative "mushroom". Her father's use of the word "Godless" to characterize Evangelistic leaders shows that, in his view, anyone who does not follow the precepts of Catholicism qualifies as irreligious. If Eugene is intolerant of Pentecostalism, he is also uncompromising towards traditional Igbo religious beliefs. He calls them not only "Godless" - a term he also applies to Nigeria's military rulers - and "ungodly" but also "heathen" and "pagan", as if they were tainted by their non-Christian origins; he further depicts the practises of Igbo religion as "sinful" and followers of the traditional movement as "idol worshipers". Any reasonable person would disagree with Eugene's contemptuous attitude towards traditional Igbo religion, a movement embodied in his own father Papa- 
Published in: English Text construction 2.1 (2009), pp. 121-131.

Status: Postprint (Author's version). Please contact John Benjamins Publishing House for further reprinting or re-use.

Nnukwu, but at the same time sympathize with his condemnation of Nigeria's military rulers. The character's indiscriminate use of derogatory religious vocabulary to criticize both forms of what he regards as "Godlessness" emphasizes the complexity of his convictions. His disdain for all forms of so-called "Godlessness" is shared by his daughter. Blinded by her veneration of Eugene, Kambili is unable to discriminate between her father's political stances, which are no doubt worthy of admiration, and his less commendable religious prejudices. At first, because she embraces every position he takes without questioning his motivations, she reproduces his value-laden linguistic choices. Her narrative contains emphatic pronouncements evocative of her father's rhetoric, among which "it was sinful for a woman to wear trousers" (80), and replicas such as "Papa-Nnukwu is a pagan" (81) or "How can Our Lady intercede on behalf of a heathen, Aunty?" (166). However, already in the early stages of the narrative, Kambili finds herself unable to bridge the chasm between the ideology her father has instilled into her and her own visual experiences. Reminiscing about her first visit to her grandfather, she reports: "I examined him [Papa-Nnukwu] that day, too, for signs of difference, of Godlessness. I didn't see any, but I was sure they were somewhere. They had to be" (63). Even though Kambili is unable to support her beliefs with concrete evidence, her convictions are still unshaken at this stage, as shown in her use of "had to" to indicate certainty. Despite her biases, when the heroine is in her grandfather's compound, she cannot help being attracted to the location, a place which she is not accustomed to but which nevertheless bears strange resemblance to more familiar surroundings:

The bench held me back, sucked me in. I watched a gray rooster walk into the shrine at the corner of the yard, where Papa-Nnukwu's god was, where Papa said Jaja and I were never to go near. The shrine was a low, open shed, its mud roof and walls covered with dried palm fronts. It looked like the grotto behind St. Agnes, the one dedicated to Our Lady of Lourdes. (66)

This description does not present Kambili as being in control of her own movements. Using the terminology of functional grammar (Halliday and Matthiessen 2004), one might describe the inanimate "bench" as the unusual Actor of material clauses, ${ }^{10}$ headed by "held back" and "sucked in", while the narrator is the Goal, i.e. the one being acted upon, in both cases. This means that she does not describe her immobility as a posture dictated by her own will, but rather as an action performed on her by the environment. This stylistic choice renders the irresistible fascination Papa-Nnukwu's shrine exerts on her. Remarkably, she also innocently 
Published in: English Text construction 2.1 (2009), pp. 121-131.

Status: Postprint (Author's version). Please contact John Benjamins Publishing House for further reprinting or re-use.

likens her grandfather's shed to the cave located behind the Catholic church in Enugu. Despite her indoctrination, she already shows intuitive knowledge of what her tolerant Aunty Ifeoma teaches her later on, namely "that sometimes what [i]s different [i]s just as good as what [i]s familiar, that when Papa-Nnukwu d[oes] his itu-nzu, his declaration of innocence, in the morning, it [i]s the same as our saying the rosary" (166). While Kambili does not comprehend her aunt's views straight away and continues to refer to her grandfather as a "heathen" and a "pagan" for much of the narrative, her curiosity about traditional Igbo culture rapidly gets the better of her. After looking at a ттио, i.e. a masquerade, and then averting her gaze from it because her grandfather tells her that women are not allowed to watch it, she tries to excuse her enjoyment of what Eugene considers "devilish folklore" (85) by making weak compromises with her conscience: "It was sinful, deferring to a heathen masquerade. But at least I had looked at it very briefly, so maybe it would technically not be deferring to a heathen masquerade" (86). The rather detailed description of the ттио preceding this passage suggests that Kambili has, despite her claims, carefully observed the masked figure. When her grandfather dies in her aunt's house during one of her stays in Nsukka, she attempts a similar linguistic subterfuge, though her priorities have perceptibly changed by then:

Jaja bent down and covered Papa-Nnukwu's body with the wrapper [...]. I wanted to go over and touch Papa-Nnukwu, touch the white tufts of hair that Amaka oiled, smooth the wrinkled skin of his chest. But I would not. Papa would be outraged. I closed my eyes then so that if Papa asked if I had seen Jaja touch the body of a heathen - it seemed more grievous, touching Papa-Nnukwu in death - I could truthfully say no, because I had not seen everything that Jaja did. (184)

Kambili is intent on exploiting the minor semantic difference between seeing Jaja "touch" Papa-Nnukwu's body and seeing him "touching" it: while the verb of perception "see" followed by a bare infinitive means that she has witnessed the entire action, the same verb followed by a present participle does not. Unlike her reflections on the incident involving the ттио, her linguistic negotiations in this passage no longer concern her actions' moral acceptability, but the relation they bear to what her father finds permissible. Taken in isolation, this development might perhaps not be interpreted as signalling a change in Kambili's attitude. Nonetheless, this line of analysis finds a decisive complement in the sentence "Papa would be outraged", preferred to the alternative "it was outrageous". While both options take the form of an attributive intensive clause, i.e. a clause in which a Carrier is 
Published in: English Text construction 2.1 (2009), pp. 121-131.

Status: Postprint (Author's version). Please contact John Benjamins Publishing House for further reprinting or re-use.

ascribed an Attribute (Halliday and Matthiessen 2004: 219), Kambili assigns a reprehensible quality to an experience in "it was outrageous", but merely speculates on her father's reaction in "Papa would be outraged". Put differently, "it was outrageous", modelled on "it was sinful" (86), would have signalled the narrator's own indignation at the situation, but "Papa would be outraged" is a comment on her father's potential wrath. Similarly, the word "heathen" occurs in indirect discourse and not free indirect thought, and may be perceived as Kambili's projection of Eugene's words, not the rendering of her own opinion. The accumulation of such textual indications leads to the emergence of a clear pattern in this extract. Indeed, while the "unacceptability" of traditional religion is still at the centre of her discourse, words signalling disapproval are no longer inserted in free indirect thought as the reflection of her judgements and beliefs; rather, they are attributed to her father, the person who sets the standards of propriety. This linguistic shift can be interpreted as marking an early ideological change.

Kambili's contact with her grandfather and elements of traditional culture allows her to gradually modify her judgement on certain issues, yet the decisive impulse is provided only when Father Amadi, a young Catholic priest with whom the heroine falls in love, exposes the irrationality of her arguments:

I was always a penitent when I was close to a priest at confession. But it was hard to feel penitent now, with Father Amadi's cologne deep in my lungs. I felt guilty instead because I could not focus on my sins, could not think of anything except how near he was. "I slept in the same room as my grandfather. He is a heathen," I blurted out.

He turned to me briefly, and before he looked away, I wondered if the light in his eyes was amusement.

"Why do you say that?"

"It is a sin."

"Why is it a sin?"

I stared at him. I felt that he had missed a line in his script. "I don't know."

"Your father told you that."

I looked away, out the window. I would not implicate Papa, since Father Amadi obviously disagreed. (175)

Kambili refuses to acknowledge the relevance of Father Amadi's remark, but the changes brought about by this conversation are clearly perceptible in the subsequent pages. After this discussion, Kambili's development is completed: ideas of sinfulness and the related concept of guilt, both of which had visibly or latently preoccupied the narrator for much of the novel, 
Published in: English Text construction 2.1 (2009), pp. 121-131.

Status: Postprint (Author's version). Please contact John Benjamins Publishing House for further reprinting or re-use.

disappear from free indirect thought, and certitudes once and for all vanish to leave room for questioning. ${ }^{11}$ From this point on, Kambili no longer refers to her grandfather or to traditional Igbo culture as "heathen" and "pagan", except in one striking case which, I believe, indicates a decisive turning point. When Eugene discovers that Papa-Nnukwu has been staying with Ifeoma while his children were also residing in the Nsukka flat, he insists on driving them back home: "I could not let them stay an extra day, Papa said, looking around the living room, toward the kitchen and then the hallway, as if waiting for Papa-Nnukwu to appear in a puff of heathen smoke" (188). Kambili's description of Eugene's expectations is indisputably - and, I would say, deliberately - inappropriate to reality. By virtue of its hyperbolic nature, the projection of her father's beliefs is an example of ironic "speech allusion", the imitation of a style of speech (Leech and Short 2007: 280). This mock exaggeration signals the critical distance the narrator has developed towards Eugene's demonization of the harmless PapaNnukwu.

Kambili arguably learns to question her father's principles, but she is never able to completely remove the aureole she has put around Eugene's head. The ambiguity of her emotions is manifest when, following her return to her aunt's house after another of her father's outbursts of violence, she refuses to speak to him on the phone but cannot rid herself of her desire to please him:

I did want to talk to Papa, to hear his voice, to tell him what I had eaten and what I had prayed about so that he would approve, so that he would smile so much his eyes would crinkle at the edges. And yet, I did not want to talk to him; I wanted to leave with Father Amadi, or with Aunty Ifeoma, and never come back. (268)

The narrator's unresolved feelings persist beyond the moment of her father s death, as shown in the closing pages of the novel, set thirty-one months after her mother has poisoned her husband. Kambili expresses a sense of relief when she reports that "a different kind of silence, one that lets [her] breathe" (305) has replaced "the silence of when Papa was alive" (305), about which she still has nightmares. Nevertheless, in spite of her distressing visions, in a paradox that epitomizes the conflicting feelings she has developed towards Eugene, she "want[s] to see him in [her] dreams", so much so that she "sometimes make[s] [her] own dreams, when [she] [is] neither asleep nor awake" (306). While Kambili has indisputably distanced herself from her father's inflexible views, many of the responses associated with his spectre are the same as those his presence induced when he was alive - a combination of love, 
Published in: English Text construction 2.1 (2009), pp. 121-131.

Status: Postprint (Author's version). Please contact John Benjamins Publishing House for further reprinting or re-use.

silence and fear.

\section{Conclusion}

This article has tried to demonstrate that Kambili's initial adherence to and subsequent rejection of her father's narrow-minded religious principles is subtly encoded in her narrative account. Yet, despite the character's newly found ideological independence, her desire to please and be loved by Eugene never completely disappears. Therefore, her intellectual development and her affection for her father, despite their close interaction, are two aspects of her personality which, textual evidence suggests, should be theoretically distinguished: while the book exposes the irrationality of the narrator's love for her father, it also suggests that her emotional attachment does not prevent a restructuring of her moral convictions. Indeed, in the course of the novel, Kambili comes to the realization that Nigerian society is not a onedimensional entity, and that catching even the slightest glimpse of its complexities, its movements and evolutions, requires that it be approached from several angles.

Thus, through the eyes of its shy but maturing narrator, Purple Hibiscus explores the differences and commonalities between two of the religious beliefs that shape contemporary Nigeria, and ultimately suggests that none can claim superiority over the other. If, from Eugene's viewpoint, the deities worshiped by his father are mere "gods of wood and stone" (47), to Papa-Nnukwu, Christ does not represent anything more than "the person that hangs on the wood outside the mission" (84). Adichie seems to indicate that, taken separately, none of these perspectives suffice to gain adequate understanding of Nigeria's multi-faceted cultural heritage.

\section{Notes}

1. "Ideology" here simply refers to "the system of beliefs, values, and categories by reference to which a person or a society comprehends the world" (Fowler 1996: 165).

2. Highfield (2005/2006) provides an analysis of the purple hibiscus, the novel's central symbol. In his view, "the flower of the title is a hybrid which represents the changes Kambili must undertake if she is to survive the abuse in her family and the corruption in her country" (2005/2006: 161). The "normality of the red hibiscuses [the flowers found in the Achikes' garden]", Highfield continues, "represents the only life Jaja and Kambili know before they visit their aunt in Nsukka" (2005/2006: 164), while the "new color that infuses Kambili and Jaja at Aunt Ifeoma's offers an escape from the hues of domestic violence that they have always known" (2005/2006: 164). 
Published in: English Text construction 2.1 (2009), pp. 121-131.

Status: Postprint (Author's version). Please contact John Benjamins Publishing House for further reprinting or re-use.

3. The phrase "speech and thought presentation" is used by Leech and Short (2007: 255-281) to refer to the way characters' speech and thought are represented in fiction. The authors decide to treat speech and thought in the same chapter because "most of the features involved in differentiating modes of character speech are paralleled by similar modes of character thought" (2007: 255).

4. Considering that this area of study has received a good deal of attention from stylisticians and literary critics alike, I do not judge it necessary to provide a definition of these terms. Useful examples, definitions and analyses are available in Leech and Short (2007: 255-281); it is on their work that the terminology used in this article is based.

5. Represented perception is "a type of discourse whereby the narrator [...] presents a character's perceptions of it, presumably as they occur in his or her consciousness and without suggesting that the character has verbalized them" (Prince 2003: 83). Since Kambili is an autodiegetic narrator, she presents her own perceptions during most of the novel.

6. Since the passage is a description of the external world as perceived by the narrator, it might also be considered a narrative statement.

7. See Fowler (1996: 66-67) for a brief stylistic application of the garden path phenomenon.

8. According to Mikhail Bakhtin, polyphony occurs when "a plurality of independent and unmerged voices and consciousnesses" co-exist in a single text (Bakhtin 1984: 6).

9. The passage that has been analyzed is not the only one in which this appears to be the case (see e.g. 67-68 and 104 for similar examples). This intertwinement of free indirect thought and free indirect speech occasionally occurs with characters other than Eugene, but the extracts involving him are by far the most relevant cases.

10. Material clauses "constru[e] a quantum of change in the flow of events as taking place through some input of energy" (Halliday and Matthiessen 2004: 179). These clauses differ from mental clauses, which express "processes of sensing" and are "concerned with our experience of the world of our own consciousness" (2004: 197) and relational clauses, which express "processes of being and having" and "serve to characterize and to identify" (2004: 210). Other process types include behavioural clauses (2004: 248-252), verbal clauses (2004: 252-256) and existential clauses (2004: 256-259).

11. In the last third of the novel, only two instances might be viewed as traces of Kambili's allegiance to her father's dogmatic views. Upon returning from Nsukka, she says: "For a moment, I wondered if Papa was right, if being with Papa-Nnukwu had made Jaja evil, had made us evil" (192, my emphasis). Importantly, the quotation takes the form of an indirect question, indicating that Kambili no longer 
Published in: English Text construction 2.1 (2009), pp. 121-131.

Status: Postprint (Author's version). Please contact John Benjamins Publishing House for further reprinting or re-use.

accepts the fact that being in contact with Papa-Nnukwu may have caused her to become "evil" without careful consideration. Furthermore, she entertains the thought only "for a moment" before dismissing it. On another occasion, Kambili reports that "we [Jaja and Kambili] both knew that Papa did not approve of people speaking in tongues because it was what the fake pastors at those mushroom Pentecostal churches did" (208, my emphasis). Here, the disdainful "fake" and "mushroom" might be interpreted as indirect speech. Even if this were not the case, none of the quotations reflect contempt for traditional Igbo religion - the view long shared by Kambili and her father, and which was challenged by Father Amadi.

\section{Works Cited}

Achebe, C. 1974. Arrow of God. 2nd ed. Oxford: Heinemann.

Adichie, C. N. 2003. Purple Hibiscus. Chapel Hill: Algonquin Books of Chapel Hill.

Adichie, C. N. 2006. Half of a Yellow Sun. London: Fourth Estate.

Bakhtin, M. 1984. Problems of Dostoevsky's Poetics. Ed. and trans. Caryl Emerson. Minneapolis / London: University of Minnesota Press.

Bruce, K. n.d. Listening to the Silences: Women's Silence as a Form of Oppression and a Mode of Resistance in Chimamanda Ngozi Adichie's Purple Hibiscus. Unpublished essay.

Bryce, J. 2008. 'Half and Half Children': Third-Generation Women Writers and the New Nigerian Novel. Research in African Literatures 39(2): 49-67.

Fowler, R. 1996. Linguistic Criticism. 2nd ed. Oxford: Oxford University Press.

Halliday, M. A. K. and C. M. I. M. Matthiessen. 2004. An Introduction to Functional Grammar. 3rd ed. London: Hodder Arnold.

Highfield, J. 2005/2006. Blood and Blossom: Violence and Restoration in Adichie's Purple Hibiscus and Vera's The Stone Virgins. International Journal of Environmental, Cultural, Economic and Social Sustainability 1(2): 161-168.

Hron, M. 2008. Ora Na-azu Nwa: The Figure of the Child in Third-Generation Nigerian Novels. Research in African Literatures 39(2): 27-48.

Leech, G. and M. Short. 2007. Style in Fiction: A Linguistic Introduction to English Fictional Prose. 2nd ed. Harlow: Pearson.

Prince, G. 2003. Dictionary of Narratology. 2nd ed. Lincoln/London: University of Nebraska Press. 